\title{
Palveluohjaus MÄÄRITTÄÄ MUISTISAIRAAN LÄHEISTEN PALVELUJEN SAAMISTA - AIKUISET LAPSET PUOLISOITA HEIKOMMASSA ASEMASSA
}

Ulla Halonen: YTM, väitöskirjatutkija, Jyväskylän yliopisto

Lina Van Aerschot: YTT, tutkijatobtori, Jyväskylän yliopisto

Tomi Oinas: YTT, yliopistotutkija, Jyväskylän yliopisto

ulla.m.halonen@student.jyu.fi; lina.vanaerschot@jyu.fi; tomi.oinas@jyu.fi

Janus vol. 29 (2) 2021, 103-121

(1) d $\|$ I

\section{Tiivistelmä}

Läheisten rooli muistisairaiden hoivaajina on jo nyt merkittävä, ja se tulee kasvamaan. Muistisairaudet yleistyvät pitkäikäisyyden lisääntyessä, ja vanhushoivapolitiikassa painotetaan kotona asumista. Tässä tutkimuksessa selvitetään muistisairaan puolisoille ja aikuisille lapsille tarjottua tiedollista tukea, palveluohjausta ja palveluja. Lisäksi tarkastellaan, millainen yhteys eri taustatekijöillä on palvelujen tarjontaan, ja miten saatu tieto ja palveluohjaus vaikuttavat tarjottuihin palveluihin. Tutkimuksen aineisto kerättiin muistisairaiden puolisoilta ja aikuisilta lapsilta sähköisellä Carer’s survey -kyselyllä. Aineiston analyysi osoittaa, että tietoa oli saatu rajallisesti ja puolisot olivat saaneet sitä enemmän kuin aikuiset lapset. Palveluohjauksen saaminen oli sattumanvaraista, vaikka palvelujen saaminen edellyttää joko tietoa palveluista ja/tai palveluohjausta. Jatkossa muistisairaan läheisten tasapuoliseen tukeen tulee kiinnittää enemmän huomiota. Erityisesti riittävään tiedon saamiseen ja palveluohjaukseen on panostettava, jotta muistisairasta läheistään hoitavat pääsevät tarvitsemansa tuen piiriin.

\section{JOHDANTO}

Muistisairaiden määrä maailmassa tulee kaksinkertaistumaan nykyisestä vuoteen 2030 ja kolminkertaistumaan vuoteen 2050 mennessä (World Health Organization 2019). Suomessa on noin 200000 muistisairasta, ja vuosittain arviolta 14500 ihmistä sairastuu etenevään muistisairauteen (Viramo \& Sulkava 2015). Muistisairaudet ovat jo nyt merkittävin tuen ja palvelun tarpeita aiheuttava sairausryhmä (Finne-Soveri ym. 2015). Lisäksi huoltosuhteen heikkeneminen aiheuttaa huomattavia muutostarpeita palvelujärjestelmälle ja hoivan organisoinnille. Muistisairauksien vaikutuksia palvelutarpeiden kasvuun ei ole useimmissa maissa riittävästi huomioitu ja ennakoitu (WHO
\& Alzheimer's Disease International 2012).

Muistisairaus ei ole vain sairastuneen sairaus, vaan se vaikuttaa myös sairastuneen lähellä oleviin ihmisiin ja yhteiskuntaan (Sosiaali- ja terveysministeriö 2012, 11). Vanhuspalvelulaissa $(980 / 2012)$ on asetettu tavoitteeksi iäkkäiden - myös muistisairaiden - asuminen kotona mahdollisimman pitkään. Suurin osa (91,2 \%) 75-vuotiaista asuukin kotona läheisten ja kotiin vietävien palvelujen turvin (Sosiaali- ja terveysalan tilastollinen vuosikirja 2020 , 58). Myös muistisairauteen sairastuneet yleensä haluavat asua omassa kodissaan.

Jotta läheisten roolia ei unohdettaisi, kansallinen muistiohjelma (STM 2012, 
5) painottaa heidän huomioimistaan osana hoivaa ja hoitoa. Tämän yksityiskohtaisemmin muistisairaan läheisten tukimuotoja ei kuitenkaan ole kirjattu vanhuspalveluja tai muistisairaita koskeviin valtakunnallisiin suosituksiin tai lakeihin. Sosiaali- ja terveyspalveluja koskevien lakien perusteella kunnat voivat itse päättää palvelujen järjestämisestä ja niiden muodoista. Muistisairaiden läheisten tuen ja palvelujen kunnalliset ja alueelliset toteutukset ovatkin varsin vaihtelevia (Finne-Soveri ym. 2015). Sairauden edetessä hoivan tarve yleensä kasvaa, ja kotona asuminen vaikeutuu. Ympärivuorokautisessa hoidossa muistisairaiden osuus on jo lähes 90 prosenttia (Kröger ym. 2018).

Merkittävää vastuuta kotona asuvista muistisairaista kantavat puolisot ja aikuiset lapset (Jolanki ym. 2013; Yeandle ym. 2013), ja heidän roolinsa on kasvamassa. Muistisairaiden läheisten tukemisesta tarvitaan lisää tietoa, jotta muistisairaiden turvallinen ja mielekäs kotona asuminen on mahdollista. Lisäksi läheisten tarvitsema tuki on myös oleellinen yhteiskuntapoliittinen kysymys: muistisairaita puolisoitaan hoitavat ovat ensinnäkin usein itsekin iäkkäitä. Heidän oma vointinsa voi hoivaamisen vuoksi heikentyä niin, että myös heistä tulee hoivan tarvitsijoita. Toiseksi muistisairaita vanhempiaan hoivaavat aikuiset lapset puolestaan ovat usein työelämässä ja heillä voi olla kotona alaikäisiä lapsia. Työurien pidentämisen ja perheiden hyvinvoinnin turvaamisen tavoitteet vaarantuvat, jos tukea ei ole tarjolla ja muistisairaan omaisen hoitaminen käy liian kuormittavaksi.
Tässä artikkelissa muistisairaiden läheisille tarkoitettu tuki on aineiston kysymysten pohjalta jaettu kolmeen eri osa-alueeseen: tiedolliseen tukeen, palveluohjaukseen ja palveluihin. Tiedollinen tuki tarkoittaa muistisairauteen liittyvää tietoa eri näkökulmista. Palveluohjaus sisältää ohjauksen lisäksi palvelutarpeiden arvioinnin, yhteyshenkilön ja hoitosuunnitelman. Palvelut tarkoittavat kotipalvelua, läheisen vapaahetkien ja -päivien järjestämistä muistisairaalle tarkoitetun päivätoiminnan ja lyhytaikaishoidon avulla, toimintaa sairastuneelle ja läheiselle, kuten erilaisia ryhmiä ja retkiä, sekä henkisen tuen eri muotoja, kuten keskusteluapua, koulutusta ja vertaistukiryhmiä.

Tässä artikkelissa selvitetään, millaista tiedollista tukea, palveluohjausta ja palveluja muistisairaiden puolisoille $\mathrm{ja}$ aikuisille lapsille on tarjottu. Lisäksi tarkastellaan, mitkä eri taustatekijät ovat yhteydessä tietoon, palveluohjaukseen ja palveluihin ja millainen yhteys tiedolla ja palveluohjauksella on muiden palvelujen tarjontaan.

Muistiliiton organisoima muistisairauteen sairastuneiden oma vaikuttamisryhmä Muistiaktiivit on ottanut kantaa heistä ja sairaudesta käytettäviin käsitteisiin ${ }^{1}$. Tässä artikkelissa noudatetaan sairastuneiden toivetta, ja käytetään seuraavia termejä: muistisairaus, muistisairas ja muistisairaan läheinen. Tässä artikkelissa läheisillä tarkoitetaan niitä aineiston puolisoita ja aikuisia lapsia $(n=333)$, jotka ovat vastanneet myöntävästi aineistossa olevaan kysymykseen "Tuen tai hoidan perheenjäsentä, joka on saanut muistisairausdiagnoosin". 


\section{LÄHEISET MUISTISAIRAAN HOIVAAJINA}

Perustuslain (1999/731) mukaan Suomessa jokaisella on oikeus saada hoivaa ja huolenpitoa silloin, kun ei itse pysty huolehtimaan itsestään. Viime kädessä vastuu on viranomaisilla ja julkisella sektorilla. Lapsilla tai puolisoilla ei ole hoivavelvollisuutta, se poistettiin lainsäädännöstä jo 1907-luvulla. Subjektiivista oikeutta palveluihin ei kuitenkaan ole kirjattu säädöksiin. Tutkijoiden mukaan vastuu hoivasta on 1990-luvulta lähtien alkanut siirtyä julkiselta sektorilta takaisin läheisille (Zechner 2010; Kröger 2009; Van Aerschot 2014). Läheisten rooli on Laura Kalliomaa-Puhan (2017) mukaan punottu sosiaalipoliittiseen järjestelmään "omaisolettamana". Kaikki eivät saa tarvitsemaansa hoivaa, jos riittäviä palveluja ei ole saatavilla eivätkä omaiset pysty auttamaan tai heitä ei ole. Tämä tarkoittaa, että osa iäkkäistä on hoivaköyhï (Kröger ym. 2019).

Työ ja terveys Suomessa 2012 -kyselyn mukaan työssäkäyvistä naisista 30 prosenttia ja miehistä 22 prosenttia huolehtii työnsä ohella apua tarvitsevasta läheisestään tämän korkean iän, sairauden tai vamman vuoksi (Kauppinen ym. 2013; vrt. Van Aerschot 2014, 120). Kotona asuvaa muistisairasta hoivaa useimmiten oma puoliso, mutta myös aikuiset lapset ovat merkittäviä hoivan antajia. Voidaan olettaa, että tulevaisuudessa muistisairauteen sairastuneet ovat aikaisempaa enemmän riippuvaisia läheisistään kuten puolisoistaan ja lapsistaan (Zwaanswijk ym. 2013; Kröger \& Leinonen 2012). Mikäli omaisiaan hoivaavia ihmisiä halutaan tukea, tarvitaan lisää tietoa muistisairaiden kotona asumisen edellytyksistä (vrt.Vilkko ym. 2010).

Muistisairaudet ovat kattokäsite usealle erilaiselle etenevälle sairaudelle, jotka vaikuttavat kognitioon, kykyyn suoriutua arkiaskareista ja asioiden hoitamisesta, sekä sosiaaliseen toimintakykyyn (Viramo \& Sulkava 2015). Muistisairauden ensimmäiset oireet, vaikutukset arkeen ja muistisairaan omaan sekä läheisten tuen tarpeisiin voivat olla hyvin erilaisia. Yksilöllisten piirteiden lisäksi esimerkiksi muut sairaudet ja muistisairauden vaihe vaikuttavat tuen tarpeisiin (esim. McCabe ym. 2016). Muistisairaudet jaetaan kolmeen vaiheeseen sairauden oireiden ja keston mukaan: varhainen tai lievä (1-2 vuotta), keskivaikea (2-5 vuotta) ja vaikea vaihe (5 vuotta ja enemmän) (WHO \& ADI 2012; Muistisairaudet: Käypä hoito suositus 2017). Tuen tarpeita sairauden eri vaiheessa ei ole juuri tutkittu eikä sairauden vaihetta ole useimmiten edes kysytty tutkimuksissa (Lethin ym. 2016a). Se kuitenkin tiedetään, että tuen tarve kasvaa sairauden edetessä (Lethin ym. 2016a) ja että ammatilliselle avulle on tarvetta kaikissa sairauden vaiheissa (Zwaanswijk ym. 2013).

Muistisairauden ensimmäisiä oireita voi olla arkisten asioiden hoitamisen vaikeutuminen. Päivittäisten askareiden hoitamista toisen puolesta tai niissä avustamista voidaan kutsua hoivaksi silloin, kun ihminen ei itse kykene niitä tekemään (Sipilä 2003, 23).Viime vuosina hoivapalveluja eli käytännössä kotihoitoa on karsittu ja kohdennettu niin, että palvelua saavat vain huonokuntoisimmat vanhukset eikä se kata kotitöihin liittyvïa asioita. Kotihoito keskittyy pääsääntöisesti henkilökoh- 
taiseen hoivaan ja käytännön kotityöt kuten siivous, kaupassakäynti ja ateriapalvelut on eriytetty tukipalveluiksi (Kröger \& Leinonen 2012; Kröger ym. 2019). Käytännössä tilanne on se, että julkisen sektorin tarjoamaa kotihoitoa saa entistä pienempi osuus ikäihmisistä, ja apua arkisissa käytännön toimissa ohjataan hankkimaan omaehtoisesti tai kunnan myöntämällä palvelusetelillä. Palvelujen hankkiminen omaehtoisesti lisää riskiä avun tarvitsijoiden eriarvoistumisesta, koska se edellyttää niin tiedon hankkimista, sopimusten tekemistä kuin taloudellisia resursseja - tai omaisten apua (Zechner 2010; KuusinenJames \& Seppänen 2013). Voidaankin todeta, että kotihoidon karsimisen ja kohdentamisen seurauksena omaisten rooli hoivan järjestämisessä on kasvanut (vrt.Van Aerschot 2014, 130-132).

\section{MUISTISAIRAAN LÄHEISTEN TUKI}

Muistisairaan läheisten on useissa kansainvälisissä tutkimuksissa todettu olevan monella tavalla kuormittuneita (esim. Wennberg ym. 2015). Läheisten tarpeiden tunnistaminen olisi tärkeää, jotta he saisivat oikeanlaista tukea oikeaan aikaan (Lethin ym. 2016b; STM 2012, 12). Tutkimuksissa muistisairaan läheisiä on useimmiten käsitelty yhtenäisenä joukkona, eikä eri roolissa olevien läheisten tuen tarpeiden mahdollisia eroja ole tutkittu (Tatangelo ym. 2018). Yleensä tutkimuksiin osallistuneet ovat olleet puolisoita, mutta myös aikuisia lapsia tai muita sukulaisia sekä ystäviä on ollut mukana (Schoenmakers ym. 2010).

Muistisairaan läheisten saama tuki on käsitteenä laaja, ja sitä voidaan jaotel- la eri tavoin: emotionaalinen tuki, välineellinen tai instrumentaalinen tuki (usein palvelut), henkinen tuki, aineellinen tuki (kuten raha) ja informatiivinen eli tiedollinen tuki. Muistisairaan läheisten tarpeet voidaan jakaa myös sairastuneen hoivaamiseen tarvittavaan tukeen sekä läheisen omiin tuen tarpeisiin (McCabe ym. 2016). Läheisen ja sairastuneen tuki ovat yhteydessä toisiinsa, sillä esimerkiksi oman ajan saamiseksi hoivaaja saattaa tarvita sairastuneelle tilapäishoitoa. Tukea voi saada julkisista palveluista, yksityiseltä sektorilta esimerkiksi ostamalla kotipalvelua tai kolmannelta sektorilta osallistumalla vertaistukiryhmiin tai muuhun toimintaan. Tutkimusten mukaan muistisairaan läheiset kokevat saavansa erittäin tärkeää tukea perheeltään, naapureiltaan ja ystäviltään (Tatangelo ym. 2018; McCabe ym. 2016), mutta sitä ei analysoida tässä artikkelissa.

Kaikkiin muistisairauksiin liittyy psyykkisten toimintojen ja käyttäytymisen muutoksia. Ne voivat olla ennalta-arvaamattomia ja vaihtelevia. (Viramo \& Sulkava 2015.) Läheisen ja sairastuneen suhde muuttuu, ja sairastuneen persoonan muuttuminen vaikuttaa läheiseen (Feast ym. 2016). Muistisairaan läheisillä on muita suurempi riski kokea stressiä, masennusta, kuormitusta ja muita terveydellisiä vaikeuksia (Wimo ym. 2012). Psyykkisen kuormituksen takia läheisillä onkin todettu olevan merkittävää henkisen tuen tarvetta (McCabe ym. 2016; Tatangelo ym. 2018; Zwaanswijk ym. 2013), ja tarpeen on todettu kasvavan muistisairaan käyttäytymisen muutosten lisääntyessä (Cova ym. 2018). Läheiset pitävät vertaistukea eräänä tärkeimmistä henkisen tuen tarpeeseen vastaavista avun muo- 
doista (Lauritzen ym. 2015; McCabe ym. 2016). Myös oman ajan saaminen esimerkiksi harrastuksiin tai lomaan on noussut tutkimuksissa keskeiseksi tarpeeksi (McCabe ym. 2016).

Puolisoitaan hoitavat naiset ovat tutkimusten mukaan kuormittuneempia kuin puolisoaan hoitavat miehet (Pöysti ym. 2012), ja joissakin tutkimuksissa aikuisten lasten on todettu olevan kuormittuneempia kuin puolisoiden (Chiao ym. 2015; Rosa ym. 2010). Aikuisten lasten on todettu kokevan erityisesti ajan puutetta ja tarvetta ulkopuolisille palveluille, jotka tukevat muistisairaan kotona asumista (Cova ym. 2018).

Henkisen tuen tarpeen ja muistisairaan läheisten oman ajan lisäksi tutkimuksissa on noussut esille tarve tiedolliselle tuelle (Chester ym. 2018; MirandaCastillo ym. 2013). Läheiset kaipasivat tietoa sairaudesta, sairauden etenemisestä, tarkasta diagnoosista sekä lääkehoidosta. Näiden lisäksi on toivottu tietoa miten suhtautua sairastuneen kognition muuttumiseen, neuvoja vuorovaikutukseen sairastuneen kanssa sekä miten valmistautua henkisesti tuleviin muutoksiin (McCabe ym. 2016; Ringer ym. 2018). Aikuisten lasten on erityisesti todettu kaipaavan tietoa käyttäytymisen muutoksista, mutta myös taloudellisista tuista (Cova ym. 2018). Lisäksi läheiset ovat kaivanneet tietoa paikallisista sosiaali- ja terveyspalveluista ja muista tukimuodoista (Zwaanswijk ym. 2013; Ringer ym. 2018) sekä käytännön neuvoja sairastuneen fyysisen, psyykkisen ja kognitiivisen toimintakyvyn ylläpitämiseen (McCabe ym. 2016). Tiedon puutteen on arvioitu olevan esteenä saatavilla olevan tuen käytölle (Lethin ym. 2016b; MacLeod ym. 2017), ja läheisten kritiikki palvelujärjestelmää kohtaan liittyykin usein tiedon tarjonnan puutteeseen (McCabe ym. 2016).

Muistisairaus alkaa näkyä vähitellen arjessa, sairastuneen kyvyssä suoriutua päivittäisistä toimista sekä itsestään huolehtimisessa. Suomessa muistisairaille ja läheisille tehdään yleensä hoito- ja palvelusuunnitelma ja tarjotaan kotona asumista tukevia palveluja kuten päivätoimintaa, kotihoitoa, kotilomitusta ja yksilöllistä terapiaa (Finne-Soveri ym. 2015, 33). Läheisten on todettu toivovan sairastuneelle tukea erityisesti aktivoivan toiminnan muodossa (Chester ym. 2018). Tällainen toiminta mahdollistaa myös hoitajille taukoa hoivasta (Lethin ym. 2019). Suomessa erilaista toimintaa sairastuneille järjestävät etenkin muistijärjestöt (Muistiliitto 2019).

Kansainvälisessä tarkastelussa läheistään hoivaaville suunnattujen palvelujen järjestämisessä on eroja erilaisten yhteiskuntajärjestelmien välillä (MirandaCastillo ym. 2013; Yeandle ym. 2013). Sama näkökulma toistuu myös kansallisella tasolla: muistisairaan ja heidän läheistensä palvelukokonaisuuksissa on todettu kuntakohtaista vaihtelua (Jolanki ym. 2013; Suhonen ym. 2015). Monimutkaisessa palvelujärjestelmässä on erityisesti korostunut palveluohjauksen tai palvelujen koordinoinnista vastaavan henkilön merkitys (Suhonen ym. 2015). Kansallisen muistiohjelman (STM 2012, 12) mukaan palveluohjauksen perustana on kattava tuen ja palvelutarpeiden arviointi, mikä puolestaan luo pohjan hoito- ja palvelusuunnitelmalle. Muistisairaiden Käypä hoito -suosituksessa (2017) muistisairaiden ja heidän läheistensä palveluohjaajaksi suositellaan muistiasioihin pe- 
rehtynyttä muistikoordinaattoria, joka ohjaa perhettä ja varmistaa palvelujen saumattomuuden. Koordinaattoritoiminnan on todettu lisäävän muistisairaan kotona asumisen kestoa (Eloniemi-Sulkava ym. 2009). Palveluohjausta on kehitetty viime vuosina runsaasti, mutta sen vaikutuksista tiedetään toistaiseksi vain vähän (Ristolainen ym. 2018).

\section{Aineisto}

Tutkimuksen aineisto kerättiin muistisairaiden läheisiltä. Alzheimer Europen toteuttamassa Carers' Survey -tutkimuksessa olivat mukana Suomi, Hollanti, Skotlanti, Tšekki ja Italia. Kyselylle haettiin lupa Bangorin yliopiston eettiseltä toimikunnalta. Kyselylomaketta muokattiin aiemmin käytetyn läheisten kyselyn (Georges ym. 2008) pohjalta. Lomakkeen pilotoinnin jälkeen kysely suomennettiin yhteistyössä Muistiliiton henkilöstön kanssa. Kysely sisälsi 56 kysymystä läheisen ja muistisairauteen sairastuneen demografisista tiedoista, sairauden ensimmäisistä oireista, sairauden diagnosointiprosessista sekä diagnosointivaiheessa ja sen jälkeen saadusta tuesta.

Uutinen ja linkki sähköisestä kyselystä julkaistiin Muistiliiton verkkosivuilla helmikuussa 2017. Lisäksi kysely lähetettiin sähköpostitse 782:1le muistisairaan läheiselle ympäri Suomea. Heidät valikoitiin systemaattisella otannalla niin, että mukaan otettiin joka kolmas muistiyhdistyksen jäsen, joka oli jäseneksi liittyessään ilmoittanut olevansa muistisairaan läheinen eikä ollut kieltänyt sähköistä markkinointia. Kyselystä tiedotettiin maaliskuussa ilmestyneessä
Muisti-lehdessä ja Muistiliiton somekanavissa. Kyselyyn vastasi 6.3. mennessä 312 henkilöä, mikä oli enemmän kuin tavoiteltu vastaajamäärä (200). Kyselyyn ei maaliskuun alun jälkeen haettu enää aktiivisesti vastauksia, mutta vastausajan sulkeutumiseen 27.3. mennessä niitä tuli vielä 51 lisää. Vastauksia saatiin Suomessa yhteensä 363, joista 7 paperilomakkeella. Sähköisen kyselyn luonteeseen kuuluen vastausprosenttia ei pysty arvioimaan. Tässä artikkelissa tutkitaan kyselyn Suomea koskevasta aineistosta puolisoiden tai kumppaneiden sekä aikuisten lasten vastauksia $(\mathrm{n}=333)$.

Aineistossa on rajoituksia, jotka on hyvä tuoda esille. Kyselyyn vastanneista puolisoista kolme neljäsosaa oli naisia ja aikuisista lapsista melkein kaikki olivat tyttäriä. Tuloksia ei siten voi soveltaa suoraan muistisairaiden läheisenä toimiviin miehiin ja aikuisiin poikiin. Vastaajat olivat myös hieman keskitasoa korkeammin koulutettuja. Korkea koulutustaso saattaa vaikuttaa niin, että vastaajat ovat keskimääräistä tietoisempia oikeuksistaan tukeen ja palveluihin. Lisäksi sähköiseen kyselyyn on voinut valikoitua vastaajiksi sellaisia läheisiä, joilla on hyvät tietotekniset taidot ja välineet, vaikka kyselyn paperiversio oli saatavissa erikseen pyydettäessä.Voidaan myös olettaa, että aktiivisimmat läheiset ovat vastanneet kyselyyn todennäköisemmin ja kuormittavimmissa hoivatilanteissa olleilla läheisillä ei välttämättä ole ollut voimavaroja vastata pitkään kyselyyn. On myös huomioitava, että osalla kyselyyn vastanneista läheisen muistisairaus oli diagnosoitu jo useita vuosia aiemmin. Läheisten voi olla vaikea jälkeenpäin muistaa kaikkea tarjolla ollutta tukea. 


\section{MitTARit JA MENETELMÄT}

Aineisto saatiin tutkimuskäyttöön anonymisoituna ja tarkistettuna SPSSdatana. Analyysimenetelminä käytettiin frekvenssejä, ristiintaulukointia ja khiin neliö -testiä. Lisäksi käytettiin Spearmanin korrelaatiotestiä, koska osa muuttujista oli järjestysasteikollisia tai jakaumat olivat vinoja. Järjestyskorrelaatioon perustuvalla osittaiskorrelaatiolla analysoitiin, miten kukin vastaajien taustatekijöistä oli yhteydessä tietoon ja palveluohjaukseen, kun muut taustatekijät vakioitiin. Edelleen analysoitiin, miten saatu tieto ja palveluohjaus olivat yhteydessä eri palvelumuotoihin, kun taustatekijät vakioitiin. Lisäksi tarkasteltiin kunkin taustatekijän suoraa yhteyttä palvelumuotoihin, kun tiedon ja palveluohjauksen välittävä vaikutus huomioitiin. Lopulta tarkistettiin saadun tiedon ja palveluohjauksen yhteys toisiinsa, kun muut tekijät vakioitiin.

Tiedollista tukea koskevassa analyysissä on huomioitava, että kyselyssä oli erikseen kysytty saatua ja haluttua tietoa. Kysymyksen asettelun vuoksi vastaajan oli mahdollista vastata myöntävästi sekä kysymykseen, että on saanut tietoa ja että olisi halunnut tietoa, mutta ei saanut sitä. Tästä syystä saatu ja haluttu tieto analysoitiin erikseen (kts. liite 1). Kyselyssä vastaajaa oli pyydetty valitsemaan jokaisen palvelumuodon kohdalla yksi seuraavista vaihtoehdoista: 1) palvelua tarjottiin, 2) palvelua tarjottiin ja sitä käytettiin ja 3) olisimme halunneet käyttää palvelua (mutta sitä ei tarjottu). Analyysissä vastausvaihtoehdot 1 ja 2 yhdistettiin muuttujaksi "palvelua tarjottiin". Samalla poistettiin toinen vastaus, jos vastaajalla oli valittuina ohjeista poiketen molemmat vaihtoehdot.
Lisäksi aineiston muuttujia yhdistettiin niin, että samaan tarpeeseen vastaavia palveluja yhdistettiin muuttujiksi joko sairastuneen tai läheisen näkökulmasta. Teknologiset apuvälineet -muuttuja jätettiin yksittäisenä erilaiseen tarpeeseen vastaavana palveluna analyysin ulkopuolelle. Yksityiskohtaiset tiedot palvelujen eri muodoista on kuvattu liitteen taulukossa kaksi.

Taustatekijöiden, saadun tiedon ja palveluohjauksen yhteyttä erilaisten palvelumuotojen tarjontaan tarkasteltiin Spearmanin järjestyskorrelaatioilla. Aikaisemman tutkimuksen ja teoriatiedon perusteella oletettiin, että tuen ja palvelujen saaminen edellyttää julkisen sektorin tarjoamaa tietoa ja / tai palveluohjausta. Tiedon saanti ja palveluohjaus voivat toteutua myös samanaikaisesti. Lisäksi oletettiin, että tietyt taustatekijät vaikuttavat tiedon, palveluohjauksen ja tuen saantiin (kts. kuvio 1). Nuorimpien eli alle 55-vuotiaiden (ns. ruuhkavuosia elävien) sekä vanhimpien eli yli 75-vuotiaiden vastaajien oman toimintakyvyn heikkenemisen arvioitiin lisäävän tuen tarpeita. Lisäksi läheisen työssä käymisen, sairastuneen sairauden keskivaikean / vaikean vaiheen tai sairastuneen yksin asumisen oletettiin kasvattavan tukija palvelumuotojen tarjontaa. Sen sijaan läheisen sukupuolella ja suhteella sairastuneeseen ei oletettu olevan yhteyttä tiedon ja palveluohjauksen saamiseen. Suoria yhteyksiä analysoitiin osittaiskorrelaatioilla muita tekijöitä vakioiden. 

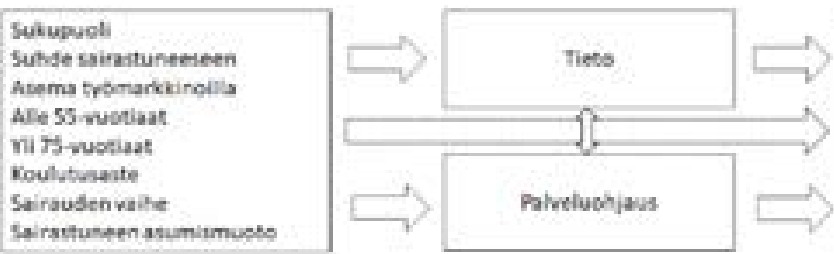

Henkinen tuki sairatuntel. Menkinen tuki iaheisetle Tavoa Bheiselit Kotipahelua sal rantuneele Toimintaa yhteilesti

Toimintan sairentuneele

Kuvio 1. Taustatekijöiden, saadun tiedon ja palveluohjauksen oletettu yhteys tarjottuihin palveluihin.

\section{TuloKseT}

Kyselyyn vastanneista 45 prosenttia ja asuivat sairastuneen kanssa. Aikuista oli puolisoita ja 55 prosenttia aikuisia lapsista yli puolet oli alle 54-vuotiaita, lapsia. Puolisoista kolme neljästä ja ai- kaksi kolmesta oli mukana työelämäskuisista lapsista 95 prosenttia oli naisia. sä ja heidän sairastuneista vanhemmisPuolisoista useimmat olivat eläkkeellä taan yli puolet asui yksin. Molempien

Taulukko 1. Vastaajien taustatiedot

\begin{tabular}{|c|c|c|c|c|}
\hline & \multicolumn{4}{|c|}{ Suhde hoidettavaan, $\mathbf{n}=\mathbf{3 3 3}$} \\
\hline & \multicolumn{2}{|c|}{$\begin{array}{l}\text { Puoliso } \\
n=149,45 \%\end{array}$} & \multicolumn{2}{|c|}{$\begin{array}{l}\text { Aikuinen lapsi } \\
\mathrm{n}=184,55 \%\end{array}$} \\
\hline Sukupuoli, $\mathbf{n = 3 3 0}$ & $\mathrm{n}$ & $\%$ & $\mathrm{n}$ & $\%$ \\
\hline Mies & 36 & $24 \%$ & 9 & $5 \%$ \\
\hline Nainen & 113 & $76 \%$ & 172 & $95 \%$ \\
\hline \multicolumn{5}{|l|}{ Ikäryhmä, n=330 } \\
\hline Alle 54 vuotta & 2 & $2 \%$ & 101 & $55 \%$ \\
\hline 55-74 vuotta & 105 & $71 \%$ & 84 & $45 \%$ \\
\hline Yli 75 vuotta & 40 & $27 \%$ & 0 & $0 \%$ \\
\hline \multicolumn{5}{|l|}{ Työmarkkina-asema, $n=333$} \\
\hline Osa- tai kokoaikainen työ & 18 & $12 \%$ & 116 & $63 \%$ \\
\hline Eläkkeellä / muu & 131 & $88 \%$ & 68 & $37 \%$ \\
\hline \multicolumn{5}{|l|}{ Korkein koulutusaste, $n=333$} \\
\hline Korkeintaan toisen asteen koulutus & 92 & $62 \%$ & 91 & $49 \%$ \\
\hline Ammattikorkeakoulu, yliopisto tai vast. & 57 & $38 \%$ & 93 & $51 \%$ \\
\hline \multicolumn{5}{|l|}{ Muistisairauden vaihe, $\mathbf{n = 3 3 3}$} \\
\hline $\begin{array}{l}\text { Lievä kognitiivinen heikentyminen / } \\
\text { varhainen vaihe }\end{array}$ & 91 & $61 \%$ & 97 & $53 \%$ \\
\hline Keskivaikea / vaikea vaihe & 45 & $30 \%$ & 68 & $37 \%$ \\
\hline Ei tietoa/ ei kerrottu & 13 & $9 \%$ & 19 & $10 \%$ \\
\hline \multicolumn{5}{|l|}{ Sairastuneen asumismuoto, $n=331$} \\
\hline $\begin{array}{l}\text { Kotona vastaajan/muiden kanssa tai } \\
\text { muualla }\end{array}$ & 145 & $98 \%$ & 81 & $44 \%$ \\
\hline Yksin & 3 & $2 \%$ & 102 & $56 \%$ \\
\hline
\end{tabular}


vastaajaryhmien koulutustaso oli tavanomaista korkeampi². Sairastuneista runsas kolmannes oli diagnoosihetkellä sairauden vaikeassa vaiheessa. Vastaajien taustatiedot (taulukko 1) ja osa tuloksista esitellään vastaajaryhmittäin, mutta korrelaatioanalyysissä niitä käsitellään yhtenä ryhmänä.

\section{Tiedollinen tuki}

Läheiset saivat kyselyssä valita 13:sta eri osa-alueesta, mitä tietoa he olivat saaneet. Vastauksissa korostuivat sairautta ja lääkehoitoa koskevat tiedot; nämä olivat ainoat osa-alueet, joista molemmista vastaajaryhmistä yli puolet olivat saaneet tietoa. Muista tiedon osa-alueista puolisot olivat saaneet merkittävästi enemmän tietoa kuin aikuiset lapset. Mikäli tietoa oli saatu, siihen oltiin melko tyytyväisiä (ka 3.61-4.08, asteikolla 1-5).

Läheiset olisivat kuitenkin halunneet saada useista asioista enemmän tietoa. Eniten tietoa olisi haluttu saada käytännön neuvoista, kuinka selviytyä ja elää hyvin muistisairauden kanssa (51\%). Tähän liittyen myös sairauden etenemisestä olisi haluttu lisää tietoa (36 \%). Toiseksi eniten olisi haluttu tietoa palveluista (45\%) ja tulevaisuuden ennakoinnista (43\%). Aikuisten lasten tiedontarve oli lähes kaikissa osa-alueissa puolisoita suurempi. Tarkat tiedot saadusta ja halutusta tiedosta on kuvattu liitteessä 1 .

\section{Palveluohjaus ja palvelut}

Puolisoille ja aikuisille lapsille tarjotuissa palveluissa oli yhteneväisyyksiä ja eroja. Puolisoille oli tarjottu enemmän palveluja kuin aikuisille lapsille. Koti- palvelu oli ainut palvelu, jota oli tarjottu tilastollisesti enemmän aikuisten lasten sairastuneille vanhemmille (45\%) kuin puolisoille ja heidän sairastuneille kumppaneilleen (25\%).

Palvelujen koordinointiin liittyviä palveluja oli tarjottu lähes yhtä paljon molemmille vastaajaryhmille. Eniten läheisille oli tarjottu palveluohjausta (45\%) ja lähes yhtä paljon palvelutarpeiden arviointia muistisairaalle (40\%). Vähän yli kolmannekselle vastaajista (36\%) oli tarjottu hoitosuunnitelmaa sairastuneelle. Läheisen palvelutarpeiden arviointia oli tarjottu alle kolmannekselle puolisoista ja vain muutamalle aikuiselle lapselle.

Puolisoille ja heidän sairastuneille läheisilleen oli tarjottu lähes kaksi kertaa useammin henkistä tukea kuin aikuisille lapsille tai heidän sairastuneille vanhemmilleen. Puolisoista 63 prosentille ja heidän sairastuneista läheisistään joka toiselle oli tarjottu henkistä tukea. Vastaavasti henkistä tukea oli tarjottu kolmannekselle aikuisista lapsista ja 29 prosentille heidän sairastuneista vanhemmistaan.

Puolisoiden sairastuneille kumppaneille oli tarjottu enemmän erilaista toimintaa (57\%) kuin aikuisten lasten sairastuneille vanhemmille (37 \%). Yhteistä toimintaa oli tarjottu tasaisemmin sekä puolisoille että aikuisille lapsille (53\% vs. $43 \%$ ). Taulukossa 2 on kuvattu eniten tarjotut palvelut tiivistettynä. Yksityiskohtaiset tiedot kaikista kysytyistä palvelumuodoista sekä eroista puolisoiden ja aikuisten lasten välillä on kuvattu liitteessä 2 . 
Taulukko 2. Palveluohjauksen ja palvelumuotojen jakautuminen

\begin{tabular}{|c|c|c|c|}
\hline \multirow[t]{2}{*}{ Tuen muoto } & \multicolumn{3}{|c|}{ Palvelua tarjottiin } \\
\hline & $\begin{array}{c}\text { Puoliso/ } \\
\text { kumppani, } \\
\mathrm{n}=149\end{array}$ & $\begin{array}{c}\text { Aikuiset } \\
\text { lapset, } \\
\mathrm{n}=184\end{array}$ & $\begin{array}{c}\chi^{2} \\
\text { p-arvo }\end{array}$ \\
\hline Nimetty yhteyshenkilö & $\begin{array}{l}49 \% \\
n=73\end{array}$ & $\begin{array}{l}42 \% \\
n=77\end{array}$ & $\begin{array}{l}\chi^{2}=1.698 \\
p=0,193\end{array}$ \\
\hline Palveluohjausta läheiselle & $\begin{array}{l}53 \% \\
n=79\end{array}$ & $\begin{array}{l}43 \% \\
n=79\end{array}$ & $\begin{array}{l}\chi^{2}=3.358 \\
p=0,067\end{array}$ \\
\hline Palveluohjausta sairastuneelle & $\begin{array}{l}50 \% \\
n=75\end{array}$ & $\begin{array}{l}51 \% \\
n=94\end{array}$ & $\begin{array}{l}\chi^{2}=.019 \\
p=0,892\end{array}$ \\
\hline Läheisen tarpeiden arviointi & $\begin{array}{l}27 \% \\
n=40\end{array}$ & $\begin{array}{l}7 \% \\
n=13\end{array}$ & $\begin{array}{l}X^{2}=24.071 \\
p<0,00\end{array}$ \\
\hline Sairastuneen tarpeiden arviointi & $\begin{array}{l}38 \% \\
n=56\end{array}$ & $\begin{array}{l}42 \% \\
n=78\end{array}$ & $\begin{array}{l}\chi^{2}=.791 \\
p=0,374\end{array}$ \\
\hline Hoitosuunnitelma sairastuneelle & $\begin{array}{l}34 \% \\
n=51\end{array}$ & $\begin{array}{l}39 \% \\
n=71\end{array}$ & $\begin{array}{l}\chi^{2}=.674 \\
p=0,412\end{array}$ \\
\hline Kotipalvelu & $\begin{array}{l}25 \% \\
n=37\end{array}$ & $\begin{array}{l}45 \% \\
n=83\end{array}$ & $\begin{array}{l}\chi^{2}=14.685 \\
p<0,00\end{array}$ \\
\hline Henkinen tuki läheiselle & $\begin{array}{l}63 \% \\
n=94\end{array}$ & $\begin{array}{l}32 \% \\
\mathrm{n}=59\end{array}$ & $\begin{array}{l}X^{2}=31.90 \\
p<0,00\end{array}$ \\
\hline Henkinen tuki sairastuneelle & $\begin{array}{l}50 \% \\
n=75\end{array}$ & $\begin{array}{l}29 \% \\
n=54\end{array}$ & $\begin{array}{l}\chi^{2}=15.28 \\
p<0,00\end{array}$ \\
\hline Taukoa läheiselle & $\begin{array}{l}46 \% \\
n=69\end{array}$ & $\begin{array}{l}44 \% \\
n=81\end{array}$ & $\begin{array}{l}\chi^{2}=.174 \\
p=0,677\end{array}$ \\
\hline Toimintaa sairastuneelle & $\begin{array}{l}57 \% \\
n=85\end{array}$ & $\begin{array}{l}37 \% \\
n=68\end{array}$ & $\begin{array}{l}\chi^{2}=13.380 \\
p<0,00\end{array}$ \\
\hline Toimintaa yhteisesti & $\begin{array}{l}53 \% \\
n=79\end{array}$ & $\begin{array}{l}44 \% \\
n=80\end{array}$ & $\begin{array}{l}\chi^{2}=3.004 \\
p=0,083\end{array}$ \\
\hline
\end{tabular}

Taustatekijöiden, tiedon ja palveluohjauksen sekä palvelujen väliset yhteydet

Taustatekijöiden sekä tiedon ja palveluohjauksen itsenäisiä yhteyksï̈ toisiinsa tarkasteltiin osittaiskorrelaation avulla kuvion 1 pohjalta. Analyysin keskeiset tulokset koottiin kuvioon 2 ensimmäisen kuvion rakennetta noudattaen. Osittaiskorrelaation tulosten lisäksi kuviossa on kuvattu palvelumuotojen sekä taustatekijöiden väliset korrelaatiot. 


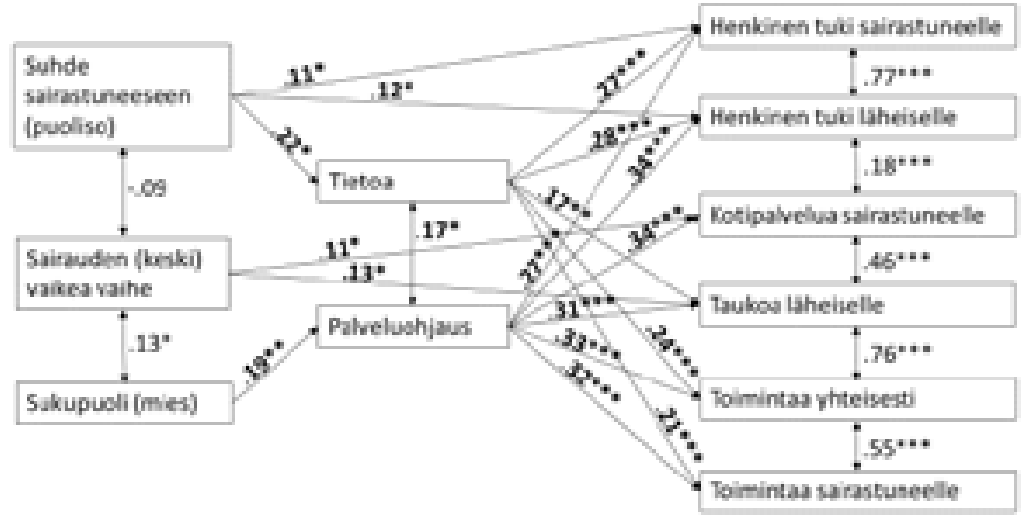

Kuvio 2. Tiedon ja palveluohjauksen yhteydet taustatekijöihin ja palveluihin Spearmanin järjestyskorrelaatioon perustuvilla osittaiskorrelaatiokertomilla (tummennettu).

Tulokset noudattivat monelta osin oletettua mallia (kuvio 1), mutta osa ennakko-oletuksista osoittautui vääriksi. Tieto ja palveluohjaus olivat oletuksen mukaisesti vahvasti yhteydessä palvelumuotoihin, toisin sanoen tuen ja palvelun saanti edellyttää tietoa ja/tai palveluohjausta. Näistä palveluohjauksen yhteys palvelumuotoihin oli vahvempi. Tieto ja palveluohjaus olivat yhteydessä toisiinsa kuten oletettiin. Sen sijaan taustatekijöiden yhteys tietoon ja palveluohjaukseen ei vastannut oletuksia. Kun muut taustatekijät vakioitiin, läheisen työssäkäynti, vastaajan alhaisempi (alle 54-vuotiaat) tai korkeampi (yli 75-vuotiaat) ikä tai sairastuneen asumismuoto eivät vastoin oletuksia vaikuttaneet tiedon ja palveluohjauksen saantiin tai tuki- ja palvelumuotojen tarjontaan. Niiden sijasta sukupuolella ja suhteella sairastuneeseen oli yhteys tiedon ja palveluohjauksen saamiseen.

Palvelumuodot olivat kaikki yhteydessä toisiinsa: jos palveluja oli tarjottu, niitä oli tarjottu yhdessä. Etenkin henkistä tukea oli usein tarjottu sekä läheiselle että sairastuneelle. Yhteistä toimintaa sairastuneelle ja läheiselle oli tarjottu usein yhtä aikaa läheiselle taukoa tarjoavien palvelujen kanssa, vaikka ne vastaavat erilaiseen tuen tarpeeseen Sairauden keskivaikeassa / vaikeassa vaiheessa oleville ja yksin asuvien muistisairaiden läheisille oli tarjottu todennäköisemmin kotipalveluja sairastuneen kotiin ja heille itselleen taukoa tarjoavia palveluja.

Puolisot olivat saaneet aikuisia lapsia enemmän tietoa palveluista. Saatu tieto puolestaan oli yhteydessä muihin palvelumuotoihin, joten puolisot olivat paremmassa asemassa tukijärjestelmässä kuin aikuiset lapset. Toisaalta on huomioitava, että korrelaatiot eivät ole kausaaliyhteyksiä, joten yhteyksien suhde voisi olla myös toisin päin: on mahdollista, että tuki- ja palvelumuodot vastaavat paremmin sairastuneiden ja puolisoiden tarpeita, joten niistä ei anneta tietoa aikuisille lapsille eikä heitä ohjata niihin yhtä usein kuin puolisoita. Pal- 
veluohjauksella oli tärkeä yhteys muiden palvelumuotojen tarjontaan, mutta ohjausta oli tarjottu sattumanvaraisesti. Miehille oli tarjottu naisia todennäköisemmin palveluohjausta, joten he ja muut ohjausta saaneet läheiset olivat muita edullisemmassa tilanteessa suhteessa muiden palvelujen tarjontaan.

\section{Pohdinta}

Tämän tutkimuksen mukaan muistisairaan läheiset eivät ole tuen saajina tasavertaisessa asemassa. Tietoa ja palveluohjausta saadaan epätasaisesti, ei avun tarvetta kasvattavien taustatekijöiden kuten sairauden vaiheen, muistisairaan yksin asumisen tai läheisen työssäkäynnin perusteella. Puolisot olivat esimerkiksi saaneet enemmän tietoa asioista, ja heille oli myös tarjottu enemmän tukea ja palveluja kuin aikuisille lapsille. Huomionarvoista oli myös se, että miehet saivat tämän aineiston mukaan todennäköisemmin palveluohjausta, mutta jos sukupuoli jätettiin huomioimatta, palveluohjaukseen pääseminen oli epätasaista ja sattumanvaraista. Palveluohjausta saaneet läheiset olivat ymmärrettävästi muita paremmassa asemassa, koska palveluohjaus oli yhteydessä muihin palvelumuotoihin. Aikuiset lapset taas jäivät tuen saajina puolisoita heikompaan asemaan. Tutkimuksen valossa on selvää, että heidän roolinsa muistisairaan läheisinä tulisi huomioida paremmin.

Muistisairaiden ja läheisten palveluja arvioivassa Muistibarometrissa (FinneSoveri ym. 2015) kunnat olivat arvioineet, että diagnoosivaiheeseen liittyvä neuvonta ja neuvontapalvelujen saatavuus on parantunut. Kaikkien barometriin vastanneiden mielestä ne olivat kohtalaisella tai hyvällä tolalla. Tässä tutkimuksessa läheisten arvio antaa tiedollisen tuen toteutumisesta erilaisen näkökulman. Tiedonsaanti keskittyi muistisairauteen ja lääkehoitoon, ja ne olivat ainoat tiedollisen tuen osa-alueet, joista yli puolet sekä puolisoista että aikuisista lapsista olivat saaneet tietoa. Kaikki läheiset toivoivat kuitenkin lisää tietoa edellä mainituista asioista. Lisäksi tietoa toivottiin saatavilla olevista palveluista sekä erityisesti siitä, miten selviytyä muistisairauden kanssa. On huolestuttavaa, että sekä puolisoista että aikuisista lapsista reilusti yli puolet ei ole saanut tietoa useimmista muistisairauden, tuen ja hoidon osa-alueista (ks. liite 1).

Tämä tutkimus osoitti, että tiedolla oli vahva yhteys palvelujen saamiseen; samalla se vahvistaa aikaisempia tutkimuksia, joissa on todettu tietämättömyyden olevan esteenä muun tuen saamiselle (Lethin ym. 2016b; MacLeod ym. 2017). Tässä tutkimuksessa puolisot olivat saaneet tietoa aikuisia lapsia todennäköisemmin ja he olivat siten myös tiedon saannin osalta aikuisia lapsia paremmassa asemassa tukijärjestelmässä. Myös palveluohjaus ja saatu tieto olivat yhteydessä toisiinsa, mikä vahvistaa kansallisen muistiohjelman (STM 2012, 12) viestiä palveluohjauksen merkityksestä tiedon jakamisessa Sen mukaan palveluohjauksella turvataan mahdollisimman monipuolinen tieto tarjolla olevista julkisen, yksityisen ja kolmannen sektorin tuesta ja palveluista.

Aikaisemman Suomessa tehdyn tutkimuksen mukaan palveluohjauksella on tärkeä merkitys asiakkaan palvelujen koordinoinnissa (Suhonen ym. 2015). 
Tässä tutkimuksessa palveluohjauksella oli vahva yhteys kaikkiin tarjottuihin palvelumuotoihin. Palveluohjausta saaneille läheisille oli todennäköisemmin tarjottu myös muita palveluita. Palveluohjauksen saaminen oli kuitenkin epätasaista eikä se ollut yhteydessä taustatekijöihin, joilla voidaan olettaa olevan yhteys suurempaan palvelujen ja palveluohjauksen tarpeeseen. Tässä tutkimuksessa palveluohjausta oli tarjottu miehille todennäköisemmin kuin naisille. Tulos on mielenkiintoinen, mutta sen yleistäminen vaatisi lisää tutkimusta, koska miehiä oli vain 14 prosenttia vastaajista.

Palveluohjaus tai sen puuttuminen riippuu siitä, miten se on kussakin kunnassa toteutettu. Muistibarometrin (Finne-Soveri ym. 2015) mukaan osassa kuntia/kuntayhtymiä on vahvasti panostettu muistisairaiden ihmisten palveluihin ja hyvinvointiin, kun toisaalla kehitys laahaa ja palvelut ovat varsin hajanaisia.

Vanhuspalvelulain (980/2012) mukaan "kunta vastaa siitä, että iäkkäälle henkilölle laaditaan sosiaalihuollon asiakkaan asemasta ja oikeuksista annetun lain 7 \:ssä tarkoitettu suunnitelma (palvelusuunnitelma)". Muistibarometrin mukaan 45 prosenttia kunnista/kuntayhtymistä huolehtii suunnitelmasta hyvällä tasolla. Tässä tutkimuksessa muistisairaiden läheisten mukaan tilanne on kuntien omaa arviota heikompi: palvelusuunnitelmaa oli läheisten mukaan tarjottu vain runsaalle kolmannekselle sairastuneista.

Kansainvälinen tarkastelu osoittaa, että väestön ikääntymisen myötä myös työssäkäyvien omaisiaan hoitavien hen- kilöiden määrä lisääntyy, mutta tuen ja palvelujen määrä ja muodot vaihtelevat suuresti (Yeandle ym., 2013). Tutkimuksemme mukaan läheisten työssäkäynnillä ei ollut tilastollisesti merkitsevää yhteyttä tuen ja palvelujen saamiseen. Vastaajista kokoaikaisesti työssä oli 37 prosenttia ja työssäkäyvistä omaistaan hoitavista suurin osa oli aikuisia lapsia. Osa-aikaisessa työssä tai työelämän ulkopuolella aikuisista lapsista oli 19 prosenttia. Aineisto ei anna kuitenkaan vastausta siihen, onko vastaaja joutunut jäämään ennenaikaisesti pois kokoaikatyöstä hoidettavansa tilanteen vuoksi (vrt. Jolanki ym. 2013). Tämän tutkimuksen valossa voidaan ainoastaan pohtia, onko tuki- ja palvelujärjestelmän puute työssäkäyvillä omaisilla vaikuttanut työajan vähentämiseen tai työnteon lopettamiseen. Oleellista olisi arvioida, kuinka suuren haitan tuen puutteet aiheuttavat ja paljonko järjestelmän kyvyttömyys tuottaa oikea-aikaista ja oikeanlaista tukea lisää myöhemmin palvelujen tarvetta, kustannuksia ja pahoinvointia (Vilkko ym. 2010). Anu Leinosen (2011) tutkimuksessa kävi ilmi, että ansiotyön ja omaishoivan yhdistämistä helpottaa merkittävästi, mikäli omaishoitajan palveluja on riittävästi tarjolla ja ne ovat toimivia.

Tämä tutkimus antaa viitteitä siitä, että palvelujärjestelmä vastaa paremmin puolisoiden kuin aikuisten lasten tarpeisiin. Aikuisten lasten roolia ja yksilöllisiä tuen tarpeita tulisi tutkia lisää. Lisäksi kunnissa olisi kiinnitettävä aiempaa enemmän huomiota muistisairaiden läheisten tasapuoliseen tukemiseen ja palvelupolun yhtenäistämiseen. Erityisesti tietoa ja palveluohjausta tulisi tarjota enemmän ja tasapuolisemmin 
kaikille muistisairaan läheisille. Kunnissa olisi tärkeää tiedostaa muistisairaiden läheisten suuri merkitys kotona asumisen mahdollistajina, ja tähän tarvittaisiin myös vahvempaa kansallista ohjausta. Tukijärjestelmän kehittäminen jää puolitiehen, jos siihen ei suunnata resursseja.

\section{KIITOKSET}

KiitosYTT Riitta Räsäselle rohkaisusta artikkelin kirjoittamiseksi ja ensimmäisen version kommentoinnista.

Kiitokset tätä tutkimusta tukeneille rahoittajille: Työllisyysrahastolle, OLVIsäätiölle ja Alli Paasikiven Säätiölle.

\section{VIITTEET}

1 Kansallinen muistiliitto organisoi muistisairaiden omaa vaikuttamiseen keskittyvää Muistiaktiivit -työryhmää. Ryhmän kokouksessa kesäkuussa 2016 oli keskusteltu muistisairauksiin liittyvistä käsitteistä. Työryhmä oli yksimielisesti päätynyt siihen, että muistisairaus on hyvä ja tunnettu yleisnimi sairaudelle, vaikka ei kuvaa sen laajaa oireistoa. Muistisairauteen sairastuneesta Muistiaktiivit toivoivat käytettävän nimityksiä muistisairas, muistisairas ihminen tai muistisairas henkilö asiayhteyden mukaan. (Muistiaktiivit, 2016.)

2 Lähes joka kolmannella työikäisellä suomalaisella oli vähintään alimman korkeaasteen tutkinto vuonna 2011. Tutkinnon suorittaneista naisten osuus on korkeampi kuin miesten (Suomen virallinen tilasto, 2012).

\section{KirJallisuUs}

Chester, Helen \& Clarkson, Paul \& Davies, Linda \& Sutcliffe, Caroline \& Davies,
Sue \& Feast, Alexandra \& Hughes, Jane \& Challis, David (2018) People with dementia and carer preferences for home support services in early-stage dementia. Aging \& Mental Health 22 (2), 270-279. https://doi.org/10.1080/13607863.201 6.1247424

Chiao, C.-Y. \& Wu, H.-S. \& Hsiao, C.Y. (2015) Caregiver burden for informal caregivers of patients with dementia: A systematic review. International Nursing Review 62 (3), 340-350. https://doi. org/10.1111/inr.12194

Cova, Ilaria \& Travi, Nicole \& Maggiore, Laura \& Cucumo, Valentina \& Mariani, Claudio \& Pomati, Simone (2018) What are the caregivers' needs on dementia care? An integrated qualitative and quantitative assessment. Neurological Sciences 39 (6), 1085-1091. https://doi. org/10.1007/s10072-018-3332-3

Eloniemi-Sulkava, Ulla \& Saarenheimo, Marja \& Laakkonen, Marja-Liisa \& Pietilä, Minna \& Savikko, Niina \& Kautiainen, Hannu \& Tilvis, Reijo S. \& Pitkälä Kaisu H. (2009) Family care as collaboration: effectiveness of a multicomponent support program for elderly couples with dementia. Randomized controlled intervention study. Journal of the American Geriatrics Society 57 (9), 2200 2208. https://doi.org/10.1111/j.15325415.2009.02564.x

Feast, Alexandra \& Orrell, Martin \& Charlesworth, Georgina \& Melunsky, Nina \& Poland, Fiona \& Moniz-Cook, Esmer (2016) Behavioural and psychological symptoms in dementia and the challenges for family carers: systematic review. The British Journal of Psychiatry 208 (5), 429-434. https://doi. org/10.1192/bjp.bp.114.153684

Finne-Soveri, Harriet \& Kuusterä, Kirsti \& Tamminen, Anna \& Heimonen, Sirkka-Liisa \& Lehtonen, Olli \& Noro, Anja (2015) Muistibarometri 2015 ja RAI-tietoa kansallisen muistiohjelman tueksi. Helsinki: Terveyden ja hyvinvoinnin laitos. http://urn.fi/ URN:ISBN:978-952-302-565-3 Luettu 15.8.2019.

Georges, Jean \& Jansen, Sabine \& Jackson, Jim \& Meyrieux, Arlette \& Sadowska, Alicja \& Selmes, Micheline (2008) Al- 
zheimer's disease in real life - the dementia carer's survey. International Journal of Geriatric Psychiatry 23 (5), 546-551. https://doi.org/10.1002/gps.1984

Jolanki, Outi \& Szebehely, Marta \& Kauppinen, Kaisa (2013) Family rediscovered? Working carers of older people in Finland and Sweden. Teoksessa Teppo Kröger \& Sue Yeandle (toim.) Combining paid work and family care, policies and perspectives in international perspective. Bristol: Policy Press, 53-69. https://doi.org/10.1332/policypress/9781447306818.003.0003

Kalliomaa-Puha, Laura (2017) Vanhuksen oikeus hoivaan ja omaisolettama. Gerontologia 31 (3), 227-242. https://doi. org/10.23989/gerontologia.63421

Kauppinen, Timo \& Mattila-Holappa, Pauliina \& Perkiö-Mäkelä, Merja \& Saalo, Anja \& Toikkanen, Jouni \& Tuomivaara, Seppo \& Uuksulainen, Sanni \& Viluksela, Marja \& Virtanen, Seppo (2013) Työ ja terveys Suomessa 2012. Helsinki:Työterveyslaitos. http://urn.fi/URN:[ISBN (pdf) 978-952-261-302-8]. Luettu 15.9.2019.

Kröger, Teppo (2009) Hoivapolitiikan rajanvetoja. Teoksessa Anneli Anttonen, Heli Valokivi \& Minna Zechner (toim.) Hoiva: tutkimus, politiikka ja arki. Tampere:Vastapaino, 99-125.

Kröger, Teppo \& Leinonen, Anu (2012) Transformation by stealth: the retargeting of home care services in Finland. Health \& Social Care in the Community 20 (3), 319-327. https://doi.org/10.1111/ j.1365-2524.2011.01047.x

Kröger, Teppo \& Van Aerschot, Lina \& Mathew Puthenparambil, Jiby (2018) Hoivatyö muutoksessa: suomalainen vanhustyö pohjoismaisessa vertailussa. Jyväskylä: Jyväskylän yliopisto. http:// urn.fi/URN:ISBN:978-951-39-7372-8 Luettu 17.4.2020.

Kröger, Teppo \& Van Aerschot, Lina. \& Mathew Puthenparambil, Jiby (2019) Ikääntyneiden hoivaköyhyys. Yhteiskuntapolitiikka 84 (2), 124-134.

Kuusinen-James, Kirsi \& Seppänen, Marjaana (2013) Ikääntyvät palvelusetelin käyttäjät valintatilanteessa: kuluttajia vai näennäiskuluttajia?” Janus 21 (4), 314329.
Lauritzen, Ulrich Jette \& Pedersen, Elgaard Preben \& Sørensen, Bender Erik \& Bjerrum, Bender Merete (2015) The meaningfulness of participating in support groups for informal caregivers of older adults with dementia: a systematic review. JBI Database of Systematic Reviews and Implementation Reports 13 (6), 373-433. https://doi.org/10.11124/ jbisrir-2015-2121

Leinonen, Anu (2011) Toimivat palvelut edellytys ansiotyön ja omaishoivan yhdistämiselle? Yhteiskuntapolitiikka 76 (5), 553-563.

Lethin, Connie \& Hallberg, Ingalill Rahm \& Karlsson, Staffan \& Janlöv, Ann-Christin (2016a) Family caregivers experiences of formal care when caring for persons with dementia through the process of the disease. Scandinavian Journal of Caring Sciences 30 (3), 526-534. https:// doi.org/10.1111/scs.12275

Lethin, Connie \& Leino-Kilpi, Helena \& Roe, Brenda \& Soto, Maria Martin \& Saks, Kai \& Stephan, Astrid \& Zwakhalen, Sandra \& Zabalegui, Adelaida \& Karlsson, Staffan (2016b) Formal support for informal caregivers to older persons with dementia through the course of the disease: an exploratory, cross-sectional study. BMC Geriatrics 16 (32), 14712318. https://doi.org/10.1186/s12877016-0210-9

Lethin, Connie \& Hanson, Elizabeth \& Margioti, Eleni \& Chiatti, Carlos \& Gagliardi, Christina \& Vaz de Carvalho, Carlos \& Malmgren Fänge, Agneta (2019) Support needs and expectations of people living with dementia and their informal carers in everyday life: a European study. Social Sciences 8 (7), 203 https://doi.org/10.3390/socsci8070203

MacLeod, Ashley \& Tatangelo, Gemma \& McCabe, Marita \& You, Emily (2017) "There isn't an easy way of finding the help that's available." Barriers and facilitators of service use among dementia family caregivers: a qualitative study. International Psychogeriatrics 29 (5), 765-775. https://doi.org/10.1017/ S1041610216002532

McCabe, Marita \& You, Emily \& Tatangelo, Gemma (2016) "Hearing Their Voice: a systematic review of dementia family 
caregivers' needs. The Gerontologist 56 (5), e70-80. https://doi.org/10.1093/ geront/gnw078

Miranda-Castillo, Claudia \& Woods, Bob \& Orrell, Martin (2013) The needs of people with dementia living at home from user, caregiver and professional perspectives: a cross-sectional survey. BMC Health Services Research 13 (1), 43-53. https://doi.org/10.1186/1472-696313-43

Muistiaktiivit (2016) Muistiaktiivien kokousmuistio 3.6.2016, ei julkaistu aineisto. Saatavilla luettavaksi Muistiliiton toimistosta.

Muistiliitto (2019) Muistiliiton ja muistiyhdistysten tapahtumat. www.muistiliitto.fi/fi/alasivut/tapahtumat. Luettu 19.10.2019.

Muistisairaudet: Käypä hoito suositus (2017) Suomalaisen Lääkäriseuran Duodecimin, Societas Gerontologica Fennican, Suomen Geriatrit -yhdistyksen Suomen Neurologisen Yhdistyksen, Suomen Psykogeriatrisen Yhdistyksen ja Suomen Yleislääketieteen Yhdistyksen asettama työryhmä. www.käypähoito.fi/hoi50044 Luettu 12.8.2019.

Pöysti, Minna Maria \& Laakkonen, Marja-Liisa \& Strandberg, Timo \& Savikko, Niina \& Tilvis, Reijo Sakari \& Eloniemi-Sulkava, Ulla \& Pitkälä, Kaisu Hannele (2012) Gender differences in dementia spousal caregiving. International Journal of Alzheimer's Disease. Article ID 162960, 5 sivua. https://doi. org/10.1155/2012/162960

Ringer,Thom J. \& Wong-Pack, Matthew \& Miller, Patricia \& Patterson, Christopher \& Marr, Sharon \& Misiaszek, Brian \& Woo, Tricia \& Sztramko, Richard \& Vastis, Peter George \& Papaioannou, Alexandra (2018) Understanding the educational and support needs of informal care-givers of people with dementia attending an outpatient geriatric assessment clinic. Ageing and Society 8 (28), 1-24. https:// doi.org/10.1017/S0144686X18000971

Ristolainen, Hanna \& Tiilikainen, Elisa \& Rissanen, Sari (2018) Kotona asuvien ikäihmisten palveluohjauksen vaikuttavuus - kuvaileva kirjallisuuskatsaus. Gerontologia 32 (4), 252-274. https:// doi.org/10.23989/gerontologia.75681
Rosa, Erika \& Lussignoli, Giulia \& Sabbatini, Federica \& Chiappa, A \& Di Cesare, S \& Lamanna, L \& Zanetti, Orazio (2010) Needs of caregivers of the patients with dementia. Archives of Gerontology and Geriatrics 51 (1), 54-58. https://doi. org/10.1016/j.archger.2009.07.008

Schoenmakers, Birgitte \& Buntinx, Frank \& Delepeleire, Jan (2010) Factors determining the impact of care-giving on caregivers of elderly patients with dementia. A systematic literature review. Maturitas 66 (2), 191-200. https://doi. org/10.1016/j.maturitas.2010.02.009

Sipilä, Jorma (2003) Hoivan organisointi: vaivaistalosta markkinatavaraksi. Janus 11 (1), 23-38.

Sosiaali- ja terveysalan tilastollinen vuosikirja 2020. Helsinki: Terveyden- ja hyvinvoinnin laitos 2021.http://urn.fi/ URN:ISBN:978-952-343-615-2. Luettu 4.5.2021.

Sosiaali- ja terveysministeriö, STM (2012) Kansallinen muistiohjelma 2012-2020. Tavoitteena muistiystävällinen Suomi. Helsinki: Sosiaali- ja terveysministeriö. http://urn.fi/ URN:ISBN:978-952-00-3224-1. Luettu 23.10.2019.

Suhonen, Riitta \& Röberg, Susanne \& Hupli, Maija \& Koskenniemi, Jaana \& Stolt, Minna \& Leino-Kilpi, Helena (2015) Muistipotilaiden optimaalisen palvelukokonaisuuden ominaisuudet". Hoitotiede 27 (4) 259-273.

Suomen perustuslaki 11.6.1999/731. Finlex.

Suomen virallinen tilasto (2012) Tieteen ja teknologian henkilövoimavarat. [verkkojulkaisu]. ISSN=1797-3228．2012， Lähes kolmannes väestöstä on korkeasti koulutettuja. Helsinki. http://www.stat.fi/ til/tthv/2012/tthv_2012_2014-03-20_ kat_001_fi.html. Luettu 15.9.2019.

Tatangelo, Gemma \& McCabe, Marita \& MacLeod, A. \& You, Emily. (2018) "I just don't focus on my needs." The unmet health needs of partner and offspring caregivers of people with dementia: A qualitative study. International Journal of Nursing Studies 77, 8-14. https://doi. org/10.1016/j.ijnurstu.2017.09.011

Van Aerschot, Lina (2014) Vanhusten hoiva 
ja eriarvoisuus, sosiaalisen ja taloudellisen taustan yhteys avun saamiseen ja palvelujen käyttöön. Acta Universitatis Tamperensis 1971. University of Tampere; Tampere University Press. http://urn.fi/ URN:ISBN:978-951-44-9568-7. Luettu 10.10.2019.

Vanhuspalvelulaki. Laki ikääntyneen väestön toimintakyvyn tukemisesta sekä iäkkäiden sosiaali- ja terveyspalveluista 28.12.2012/980. Finlex.

Vilkko, Anni \& Finne-Soveri, Harriet \& Heinola, Reija (2010) Ikäihmisten palvelutarpeet ja saatu apu. Teoksessa Marja Vaarama, Pasi Moisio \& Sakari Karvonen (toim.) Suomalaisten hyvinvointi 2010. Helsinki:Terveyden- ja hyvinvoinnin laitos, 44-59. http://urn.fi/URN:NBN:fife201205085398. Luettu 18.8.2019.

Viramo, Petteri \& Sulkava, Raimo (2015) Muistisairauksien epidemiologia. Teoksessa Timo Erkinjuntti, Anne Remes, Juha Rinne, Hilkka Soininen, Irina Alafuzoff \& Seppo Piispa (toim.) Muistisairaudet. 2. uud. p. Helsinki: Duodecim, 35-43.

Wennberg, Alexandra \& Dye, Cheryl \& Streetman-Loy, Blaiz \& Pham, Hiep (2015) Alzheimer's patient familial caregivers: a review of burden and interventions". Health \& Social Work 40 (4), 162-169. https://doi.org/10.1093/hsw/ hlv062

Wimo, Anders \& Jönsson, Linus \& Bond, John \& Prince, Martin \& Winblad, Begnt (2012) The worldwide economic impact of dementia 2010. Alzheimer's \& Dementia: Journal of the Alzheimer's Association 9 (11), 1-11. https://doi. org/10.1016/j.jalz.2012.11.006
World Health Organization \& Alzheimer's Disease International (2012) Dementia: a public health priority. World Health Organization. https:// apps.who.int/iris/bitstream/handle/10665/75263/9789241564458_eng. pdf?sequence $=1$ Luettu 16.9.2019.

World Health Organization, WHO (2019) Risk reduction of cognitive decline and dementia: WHO Guidelines, France. https://apps.who.int/iris/bitstream/ha ndle/10665/312180/9789241550543eng.pdf?ua=1. Luettu 16.9.2019.

Yeandle, Sue \& Kröger, Teppo \& Cass, Bettina \& Yueh-Ching, Chou \& Shimmei, Masaya \& Szebehely, Marta (2013) The emergence of policies supporting working carers in six countries. Teoksessa Teppo Kröger \& Sue Yeandle (toim.) Combining paid work and family care, policies and perspectives in international perspective. Bristol: Policy Press, 23-52. https://doi.org/10.1332/policypress/9781447306818.003.0002

Zechner, Minna (2010) Informaali hoiva sosiaalipoliittisessa kontekstissa. Acta Universitatis Tamperensis 1543. University of Tampere; Tampere University Press. http://urn.fi/ urn:isbn:978-951-44-8190-1

Zwaanswijk, Marieke \& Peeters, José M \& Van Beek, Adriana PA \& Meerveld, Julie HCM \& Francke, Anneke L (2013) Informal caregivers of people with dementia: problems, needs and support in the initial stage and in subsequent stages of dementia: a questionnaire survey. The Open Nursing Journal 7 (1), 6. https://doi. org/10.2174/1874434601307010006 


\section{Liite 1.}

\begin{tabular}{|c|l|l|l|l|l|l|}
\hline $\begin{array}{l}\text { Mitä tietoa sait / olisit halunnut saada } \\
\text { sairauteen liittyen }\end{array}$ & Puoliso & $\begin{array}{l}\text { Aikuiset } \\
\text { lapset }\end{array}$ & p-arvo & Puoliso & $\begin{array}{l}\text { Aikuiset } \\
\text { lapset }\end{array}$ & p-arvo \\
\hline Muistisairaudesta & $\begin{array}{l}63,1 \% \\
\mathrm{n}=94\end{array}$ & $\begin{array}{l}60,3 \% \\
\mathrm{n}=111\end{array}$ & 0,344 & $\begin{array}{l}14,1 \% \\
\mathrm{n}=21\end{array}$ & $\begin{array}{l}22,8 \% \\
\mathrm{n}=42\end{array}$ & 0,434 \\
\hline Sairauden etenemisestä & $\begin{array}{l}40,9 \% \\
\mathrm{n}=61\end{array}$ & $\begin{array}{l}35,3 \% \\
\mathrm{n}=65\end{array}$ & 0,174 & $\begin{array}{l}34,9 \% \\
\mathrm{n}=52\end{array}$ & $\begin{array}{l}41,3 \% \\
\mathrm{n}=74\end{array}$ & 0,232 \\
\hline Lääkehoidoista & $\begin{array}{l}67,8 \% \\
\mathrm{n}=101\end{array}$ & $\begin{array}{l}52,7 \% \\
\mathrm{n}=97\end{array}$ & $0,004 * *$ & $\begin{array}{l}15,4 \% \\
\mathrm{n}=23\end{array}$ & $\begin{array}{l}28,8 \% \\
\mathrm{n}=53\end{array}$ & $0,004 * *$ \\
\hline Muistiliitosta / muistiyhdistyksestä & $\begin{array}{l}59,1 \% \\
\mathrm{n}=88\end{array}$ & $\begin{array}{l}29,9 \% \\
\mathrm{n}=55\end{array}$ & $0,00 * * *$ & $\begin{array}{l}12,1 \% \\
\mathrm{n}=18\end{array}$ & $\begin{array}{l}31,0 \% \\
\mathrm{n}=57\end{array}$ & $0,00 * * *$ \\
\hline Muista tarjolla olevista apu /tukiryhmistä & $\begin{array}{l}36,2 \% \\
\mathrm{n}=54\end{array}$ & $\begin{array}{l}14,7 \% \\
\mathrm{n}=27\end{array}$ & $0,00 * * *$ & $\begin{array}{l}25,5 \% \\
\mathrm{n}=38\end{array}$ & $\begin{array}{l}45,1 \% \\
\mathrm{n}=83\end{array}$ & $0,00 * * *$ \\
\hline Tarjolla olevista palveluista & $\begin{array}{l}40,9 \% \\
\mathrm{n}=61\end{array}$ & $\begin{array}{l}16,8 \% \\
\mathrm{n}=31\end{array}$ & $0,00 * * *$ & $\begin{array}{l}34,2 \% \\
\mathrm{n}=51\end{array}$ & $\begin{array}{l}54,3 \% \\
\mathrm{n}=100\end{array}$ & $0,00 * * *$ \\
\hline Terveistä elämäntavoista, joilla hidastaa & $\begin{array}{l}47,7 \% \\
\mathrm{n}=71\end{array}$ & $\begin{array}{l}17,4 \% \\
\mathrm{n}=32\end{array}$ & $0,00 * * *$ & $\begin{array}{l}6,7 \% \\
\mathrm{n}=10\end{array}$ & $\begin{array}{l}22,3 \% \\
\mathrm{n}=41\end{array}$ & $0,00 * * *$ \\
\hline sairauden etenemistä? & $\begin{array}{l}38,3 \% \\
\mathrm{n}=57\end{array}$ & $\begin{array}{l}23,4 \% \\
\mathrm{n}=43\end{array}$ & $0,02 * *$ & $\begin{array}{l}45,6 \% \\
\mathrm{n}=68\end{array}$ & $\begin{array}{l}54,9 \% \\
\mathrm{n}=101\end{array}$ & 0,093 \\
\hline Käytännön neuvoja, kuinka selviytyä ja elää \\
hyvin muistisairauden kanssa?
\end{tabular}


Liite 2. Tarkat tiedot puolisoille ja aikuisille lapsille tarjotuista palveluista

\begin{tabular}{|c|c|c|c|}
\hline $\begin{array}{l}\text { Mitä palveluita teille tarjottiin diagnoosin ja sitä seuranneiden kuuden (6) } \\
\text { kuukauden aikana. }\end{array}$ & Puoliso & $\begin{array}{l}\text { Aikuiset } \\
\text { lapset }\end{array}$ & p-arvo \\
\hline Muistisairaan tarpeiden arviointi & $\begin{array}{l}38 \% \\
\mathrm{n}=56\end{array}$ & $\begin{array}{l}42 \% \\
\mathrm{n}=78\end{array}$ & 0,374 \\
\hline Sinun tarpeidesi arviointi läheisenä & $\begin{array}{l}27 \% \\
\mathrm{n}=40\end{array}$ & $\begin{array}{l}7 \% \\
n=13\end{array}$ & $0,000^{*}$ \\
\hline $\begin{array}{l}\text { Nimetty henkilö tai palvelu, joka tarjoaisi palveluohjausta ja johon voisitte ottaa } \\
\text { tarvittaessa yhteyttä }\end{array}$ & $\begin{array}{l}49 \% \\
\mathrm{n}=73\end{array}$ & $\begin{array}{l}41 \% \\
n=76\end{array}$ & 0,161 \\
\hline Vertaistukiryhmä läheisille/omaisille & $\begin{array}{l}53 \% \\
\mathrm{n}=79\end{array}$ & $\begin{array}{l}26 \% \\
\mathrm{n}=47\end{array}$ & $0,000^{*}$ \\
\hline Vertaistukiryhmä muistisairaalle & $\begin{array}{l}43 \% \\
n=64\end{array}$ & $\begin{array}{l}28 \% \\
\mathrm{n}=51\end{array}$ & 0,004 \\
\hline Ystävä toiminta - vapaaehtoisen tuki / tapaaminen & $\begin{array}{l}16 \% \\
n=24\end{array}$ & $\begin{array}{l}19 \% \\
n=34\end{array}$ & 0,571 \\
\hline Neuvontaa / henkistä tukea muistisairaalle & $\begin{array}{l}20 \% \\
n=30\end{array}$ & $\begin{array}{l}11 \% \\
n=21\end{array}$ & 0,028 \\
\hline Neuvontaa / henkistä tukea läheiselle/omaiselle & $\begin{array}{l}27 \% \\
n=40\end{array}$ & $\begin{array}{l}16 \% \\
n=29\end{array}$ & 0,013 \\
\hline Koulutusta/kurssi läheiselle/omaiselle & $\begin{array}{l}34 \% \\
\mathrm{n}=50\end{array}$ & $\begin{array}{l}13 \% \\
n=24\end{array}$ & $0,000^{*}$ \\
\hline Tuettu loma & $\begin{array}{l}33 \% \\
n=49\end{array}$ & $\begin{array}{l}11 \% \\
n=21\end{array}$ & $0,000^{*}$ \\
\hline Päivätoiminta & $\begin{array}{l}39 \% \\
n=58\end{array}$ & $\begin{array}{l}39 \% \\
n=72\end{array}$ & 0,970 \\
\hline Kotipalvelu - apua kotitöissä & $\begin{array}{l}20 \% \\
n=30\end{array}$ & $\begin{array}{l}34 \% \\
\mathrm{n}=62\end{array}$ & 0,006 \\
\hline Kotipalvelu - apua henkilökohtaisessa hoidossa & $\begin{array}{l}16 \% \\
n=24\end{array}$ & $\begin{array}{l}41 \% \\
n=75\end{array}$ & $0,000^{*}$ \\
\hline $\begin{array}{l}\text { Apua kotona - maksettu työntekijä vierailemaan ja muita yhteisiä aktiviteetteja } \\
\text { varten muistisairaan kanssa, ulkoilua jne. }\end{array}$ & $\begin{array}{l}15 \% \\
\mathrm{n}=23\end{array}$ & $\begin{array}{l}20 \% \\
\mathrm{n}=37\end{array}$ & 0,270 \\
\hline Lyhytaikaishoito - tarjoaa tauon omaishoitajalle & $\begin{array}{l}27 \% \\
\mathrm{n}=40\end{array}$ & $\begin{array}{l}19 \% \\
\mathrm{n}=35\end{array}$ & 0,089 \\
\hline Teknologiset apuvälineet (esim. liikkeentunnistimet, hälyttimet jne.) & $\begin{array}{l}16 \% \\
\mathrm{n}=24\end{array}$ & $\begin{array}{l}23 \% \\
\mathrm{n}=42\end{array}$ & 0,126 \\
\hline Kognitiivinen harjoittelu / Muistiryhmä muistisairaalle & $\begin{array}{l}29 \% \\
\mathrm{n}=43\end{array}$ & $\begin{array}{l}13 \% \\
\mathrm{n}=23\end{array}$ & $0,000^{*}$ \\
\hline Elämäntarina / muistelutyötä muistisairaalle & $\begin{array}{l}13 \% \\
\mathrm{n}=20\end{array}$ & $\begin{array}{l}5 \% \\
\mathrm{n}=9\end{array}$ & 0,006 \\
\hline Muistin tuki / muistin treenaamista muistisairaalle & $\begin{array}{l}20 \% \\
\mathrm{n}=29\end{array}$ & $\begin{array}{l}6 \% \\
\mathrm{n}=11\end{array}$ & $0,000^{*}$ \\
\hline Luovaa toimintaa muistisairaalle - taiteita, musiikkia jne. & $\begin{array}{l}24 \% \\
\mathrm{n}=35\end{array}$ & $\begin{array}{l}10 \% \\
\mathrm{n}=18\end{array}$ & 0,001 \\
\hline Muu toimintaryhmä muistisairaalle liikuntaa, sosiaalista toimintaa, retkiä jne. & $\begin{array}{l}36 \% \\
\mathrm{n}=54\end{array}$ & $\begin{array}{l}17 \% \\
\mathrm{n}=32\end{array}$ & $0,000^{*}$ \\
\hline Muistikahvila & $\begin{array}{l}32 \% \\
\mathrm{n}=47\end{array}$ & $\begin{array}{l}11 \% \\
\mathrm{n}=21\end{array}$ & $0,000^{*}$ \\
\hline
\end{tabular}

